\title{
Framing Contests Between Dutch Activists and Local News Media: The Eurodusnie Anarchist Group, Leiden, 1997-2002
}

\begin{abstract}
In order to gain a better understanding of the dynamics between activists and mainstream media, this paper analyses the ways in which the Dutch, Leiden-based anarchist collective Eurodusnie (1997-2002) responded to negative publicity. While many have described the relationship between social movements and the mass media as asymmetric, assigning a dominant role to mass media, our paper emphasises the agency of a local social movement and the strategies it employed to counter negative media frames. It does so through a systematic analysis of 250 Leidsch Dagblad news reports and Eurodusnie's varied responses to them, highlighting the collective's knack for 'exploiting' the mass media's own logic in order to counter negative frames and further their own.
\end{abstract}

\section{Keywords}

social movements; anarchism; alterglobalism; media politics; media activism

\section{Introduction}

In April 1997, a group of activists based in the Dutch town of Leiden (the Netherlands) founded Eurodusnie (1997-2010). Eurodusnie (i.e., 'we don't want no euro' - the name is a pun and refers to the amusement park Euro Disney) was an anarchist-inspired collective that protested against neoliberal globalisation and, in particular, European unification and the introduction of the euro. ${ }^{1}$ Initially founded for a one weekend 'counter-summit' to be organised in parallel with the 1997 Amsterdam European Summit, it soon evolved into a local activist group. Although based in Leiden, it gained national and even international notoriety, hosting an international meeting of the alterglobalist network People’s Global Action in 2002, mobilising for various international anti-summit protests, and launching one of the first 'weggeefwinkels' ('free shops'). Its major claim to fame was 'pieing': between 1998 and 2000, Eurodusnie activists threw pies in the faces of three politicians as an act of protest against neoliberal politics. 


\section{EuroDusnie intern}

Wat valt er te melden deze keer? Nou ja dat eigenlijk alles z'n goede gangetje gaat. Tot natuurlijk de Telegraaf niets wist te schrijven en op de proppen kwam met het verhaal dat hordes 'linksen' hun geliefde vorstin te lijf zouden gaan. Het lijkt wel of ze ernaar uit kijken. Dat er naar iets leuks uit te kijken valt op 29a kun je lezen in het interview met COMODO.

In ieder geval werkt de Leidse gemeente hard aan een plaatselijke noodverordening, en ziet het er naar uit dat de horeca gelegenheden langs de route hun buiten taps wel kunnen vergeten. Goed, we hebben gisteren een goede documentaire gezien van Hanneke Willemse over anarchistische alternatieven tijdens de Spaanse Burgeroorlog in het eetcafe 'Las Vegas'. Over twee maanden komt er een

(O) soortgelijke informatieavond

over anarchistische alternatieven die er in Rusland zijn geweest en zijn. Verder draait het dagcafé op zaterdagmiddag sinds een paar weken en kun je op zaterdagmiddagen tegenwoordig de

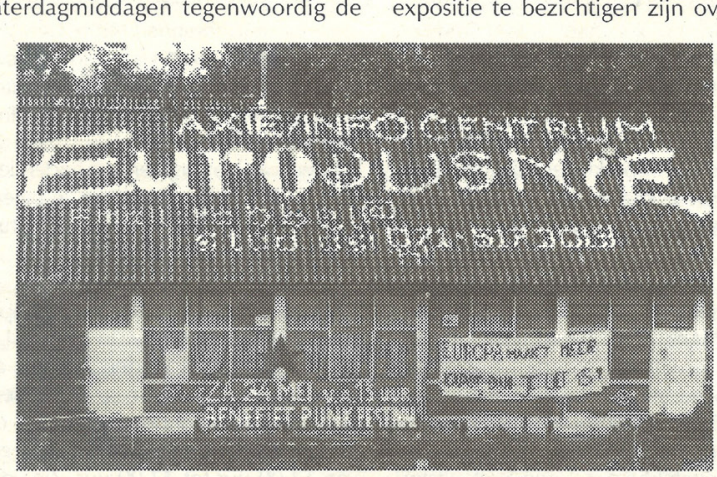

Ons gebouw aan de Boerhaavelaan weggeefwinkel, de infowinkel en voedselcoöperatie 'Tegengif' en eetcafé 'Las Vegas' tegelijkertijd bezoeken. In april zal in eetcafé 'Las Vegas' tevens een expositie te bezichtigen zijn over de

wereldwijde strijd tegen monarchieën En in het weekend van 31 maart, 1 en 2 april, vieren we groot feest, want dan bestaat EuroDusnie 3 jaar en iedereen is natuurlijk uitgenodigd om dit met ons mee te vieren. Het wordt een spetterend feest en er komen interessante discussies. Meer hierover kun je elders in Dusnieuws lezen. Het allerlaatste nieuws is dat Zwarte Sterren op vrijdag 28 april, de dag voor koninginnedag, een benefietconcert organiseert voo COMODO. Wie precies komen is no niet geheel duidelijk maar in ieder geval speelt de Antifare uit Antwerpen. Een laatste bericht voor de internetters onder ons: ons nieuwe adres: http:// squat.net/eurodusnie

\section{DUSNIEUWS to}

Figure 1. Initially, Eurodusnie acted from the squatted school building at the Boerhaavelaan, Leiden (shown on the photo). Later, the collective also squatted a cultural centre in Leiden's city centre at the Koppenhinksteeg. "Eurodusnie intern," Dusnieuws 19 (February 2000).

This paper analyses the media strategies of Eurodusnie, the ways in which local mainstream media reported on Eurodusnie's actions, and the ways in which Eurodusnie subsequently responded to these news reports. It does so through a framing analysis, which focuses on the ways in which local news media presented Eurodusnie to their audiences, and the counter-framing strategies that Eurodusnie activists developed in response. By analysing these interactions between local media and local activists, we can gain a better understanding of social movement media strategies and their effects.

Eurodusnie was both a local social movement and a subculture, characterised by squatting, veganism, and 'punk' clothing and hairstyles. Their potential for disruptive action together with their subcultural image made Eurodusnie members prime candidates for the status of folk devils, defined by Cohen as outsiders presented by sensationalist media accounts as deviants, criminals, and subverters of social and political order. ${ }^{2}$ Folk devils are often 'created' by the media and are traditionally supposed to exert little to no influence over their image, but Eurodusnie's folk devils talked back: they were not a passive object of news media framing, but a pro-active subject, actively engaged in establishing and adjusting the frames used by the media. To resist these frames designed 
to marginalise and criminalise them, they responded to the media, demonstrating their media savvy by exploiting news media routines and formats, and using alternative media to push their favoured frames. ${ }^{3}$ This paper thus presents a case study of how one group of local activists involved in spectacular, subversive activism dealt with negative publicity.

The case study of Eurodusnie also serves to test Rucht's 'quadruple A' categorisation of social movement media strategies, gauging its analytical value and proposing an adaptation of the model in order to improve it. ${ }^{4}$ The interactions between politics, activists and the media have received much scholarly attention. ${ }^{5}$ Gamson and Wolfsfeld have characterised the relationship between activists and the media as a tense one: "Send my message," say the activists; "Make me news," say the journalists. ${ }^{6}$ Protesters and news media need each other, but for different reasons. The former aim to receive as much (positive) media attention as possible, while the latter wish to cover newsworthy events. As both groups devise different strategies to further their goals, tensions arise. Protesters may take recourse to spectacular forms of action to attract publicity. However, since negativity is a major news value ${ }^{7}$ and establishment sources hold the privileged position of being primary definers, ${ }^{8}$ the result may be that activists protesting the status quo find themselves framed in an unfavourable way. Then again, activists are not completely at the mercy of other actors: they often succeed in using the mass media to further their own ends. ${ }^{9}$

Rucht identifies four media strategies that activists have used since the 1960s: 'the quadruple A'. Activists may shun mass media altogether (Abstention), denounce unfair coverage of their actions (Attack), use news media logics to their own benefit (Adaptation), and publish their own media (Alternatives). Activists may also use various combinations of these strategies, and Eurodusnie indeed employed all four. According to Rucht, three consecutive generations of activists during the period 1960-2000 the New Left of the 1960s, the new social movements of the 1970s and 1980s, and the movements against neoliberal globalisation in the 1990s - emphasised different components of the quadruple A. Eurodusnie, a local anarchist group with transnational connections, belonged to the third category, which, according to Rucht, was generally moderate in its dealings with mainstream news media unless it faced criminalisation (Attack).

By investigating the media strategies of Eurodusnie, our research also contributes to the emerging field of research on activism beyond the metropolis. Research on social movements has traditionally focused on (inter)national protest movements or on urban movements in capital cities. ${ }^{10}$ Only recently has attention broadened to include protest in smaller towns and cities, ${ }^{11}$ but such 
research has not focused on these local movements' relations with (local) media. Thus, while the media politics of anarchist metropolitan movements such as Provo and the squatters movement have received extensive attention, ${ }^{12}$ far less attention has been paid to local movements in smaller cities and towns, and to their interaction with local and/or national news media.

\section{Sources and method}

This study is based on three source types. At the centre stands a systematic analysis of 250 news articles on Eurodusnie published by Leiden's regional newspaper Leidsch Dagblad between 1997 and $2005 .{ }^{13}$ Analysing these news reports enables a detailed analysis of the interaction between local activists and local media. Leidsch Dagblad was Leiden's only regional daily newspaper at that time, with an extensive local news staff and a print run of 36,761 in 2004. In that year, Leiden counted 118,700 inhabitants, although it must be borne in mind that Leidsch Dagblad was not only distributed in Leiden but also in the wider region. The newspaper had a centre to centre-right outlook, while its local news reporting was generally not politically informed. The newspaper was an important source for Leiden's local news, although it had to compete with hyperlocal digital and print news outlets, such as sleutelstad.nl and several free local weeklies such as Leids Nieuwsblad, Witte Weekblad and Het Op Zondag. News articles on contentious actions by Eurodusnie are analysed to assess how events were presented and how they were framed, revealing which elements were highlighted or downplayed in order to convey a preferred reading. Subsequently, an analysis is made of when, why and how Eurodusnie activists responded to unfavourable frames, and with what results.

The second, supplementary, source is the newsletter that Eurodusnie published irregularly between 1997 and 2003, Dusnieuws, which had a print run of several hundred and was available for free at the two Eurodusnie social centres and at various locations in the city, such as the library, as well as being sent to ideologically related social centres throughout the country. ${ }^{14}$ In Dusnieuws, Eurodusnie activists presented themselves and their initiatives, commented on local and world politics and engaged in discussions with activists from other groups and parties. The newsletter is especially interesting for our research because Eurodusnie activists frequently reflected on their own media politics and their relationship towards local and mainstream media.

Finally, this study draws on additional print and oral history sources to contextualise the information collected from the previous two sources. National newspaper reports were analysed, but not in a systematic fashion, because the present study focuses on the interaction between local activists and local media. ${ }^{15}$ Even so, national newspaper reports provided useful background 
information. In a similar way, semi-structured interviews with two former Eurodusnie activists and two Leiden journalists helped to contextualise information and gain insight into the ways local activists and local journalists interacted. During these interviews, we asked Eurodusnie activists how they interpreted local news reporting and what strategies they devised for dealing with local journalists, while we asked local journalists how they interacted with Eurodusnie activists and responded to their strategies. As with national newspaper reports, this source type has not been analysed systematically, since the focus of our research is the framing and counter-framing of local activists and local news media through their mediums (i.e., Leidsch Dagblad and Dusnieuws).

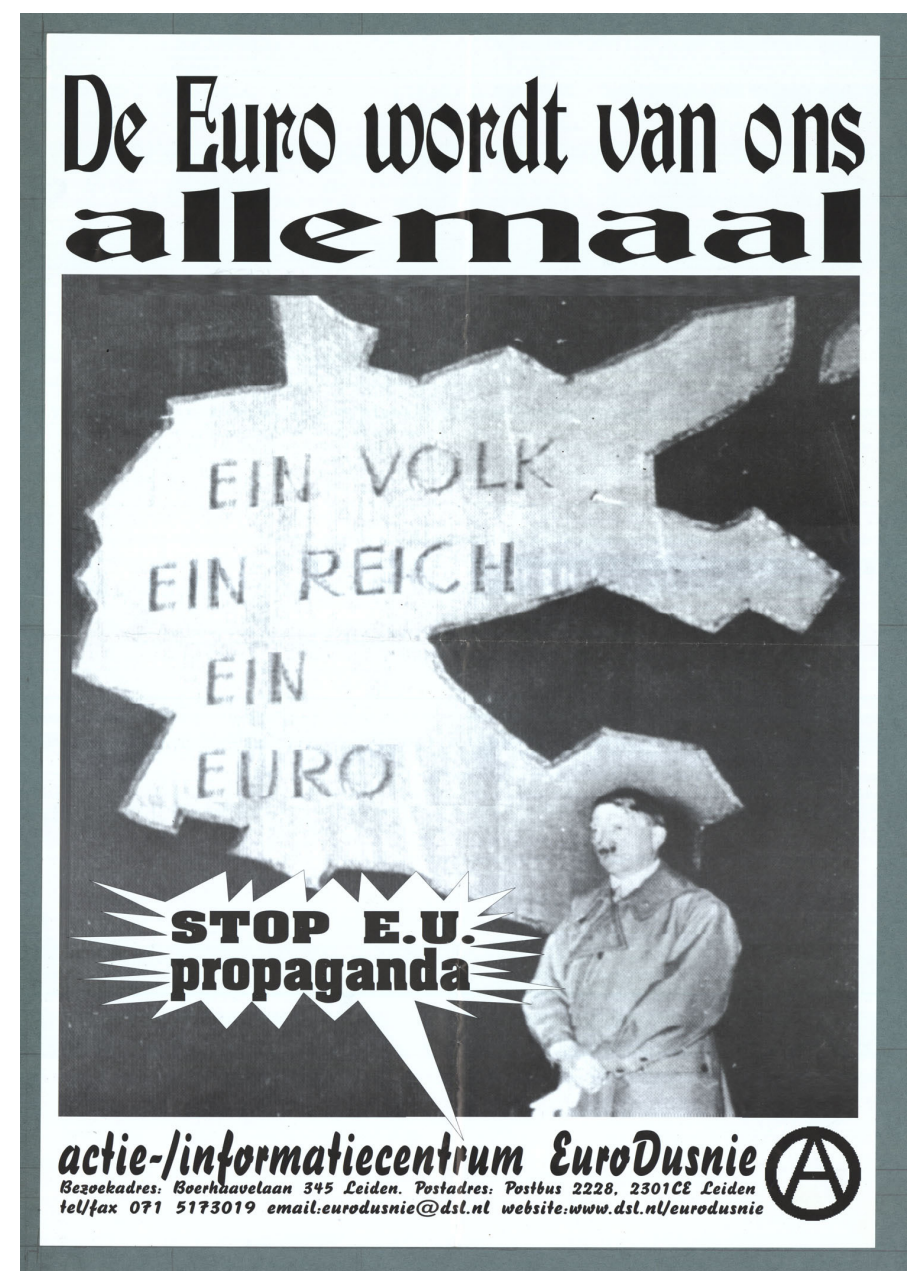

Figure 2. Poster Eurodusnie, "De Euro wordt van ons allemaal” (2001). Eurodusnie activists soon discovered that spectacular actions or images could garner media attention. The printing and distribution of a poster that showed Hitler in front of the slogan 'Ein Volk, Ein Reich, Ein Euro' was one example of the collective's provocative media strategy. Collection International Institute of Social History, https://resolver.kb.nl/resolve?urn=urn:gvn:NAGO02:II SG-30051001833422. 
The method employed in this research is a framing analysis. Gamson and Wolfsfeld define a frame as a 'central organizing idea, suggesting what is at issue'. ${ }^{16}$ When a situation is 'framed', certain facts are highlighted, connected, and imbued with a specific meaning. According to Entman's classic definition, 'to frame is to select some aspects of a perceived reality and make them more salient in a communicating text, in such a way as to promote a particular problem definition, causal interpretation, moral evaluation and/or treatment recommendation for the item described'. ${ }^{17}$ Framing is often strategic, and can therefore easily become contested. When Leiden's main local media outlet, Leidsch Dagblad, negatively framed the actions by Eurodusnie, this was bound to elicit responses by Eurodusnie activists, but the latter also employed more subtle ways to influence local news framing. To analyse these dynamics, the news reports in Leidsch Dagblad have been grouped into clusters of reports discussing specific actions, mapping how journalists described actions and if and how activists responded to (un)favourable news reporting.

Based on a systematic analysis of all 250 Leidsch Dagblad reports on Eurodusnie and the ensuing framing contests, the present study highlights the four most important news events in terms of the amount of coverage, during which news reporting was either particularly contested or exemplified the dynamics between local journalists and local activists. The remaining cases did not yield any new media strategies, so we consider the four we discuss as representative.

\section{The history and media politics of Eurodusnie, 1997-2002}

Eurodusnie was formed in 1997, when a small Leiden-based group started preparations for a countersummit against the meeting of EU ministers of foreign affairs in the coastal town of Noordwijk, some 15 kilometres from Leiden. The group decided to squat an empty hotel there, but they were evicted on the same day. The activists then decided to squat a backup location: an old and disused school building on Boerhaavelaan in Leiden. There, the counter-summit took place over a weekend, after which the Leiden group decided to continue activities at the squatted school building. In the course of a few months, the group grew to the size of thirty to forty people, who organised lectures, debates, movie nights and parties, while at the same time organising a weekly vegan diner and a free shop. After a year, the group squatted a second building in Leiden city centre, on Koppenhinksteeg. ${ }^{18}$

In its early years, Eurodusnie organised and took part in confrontational actions, both in Leiden and beyond. In 1998, for example, Eurodusnie activists occupied the Ministry of Finance in The Hague 
and symbolically 'dumped' human rights and environmental laws in front of the Amsterdam Stock Exchange. In 1999, the squatting of a building on Aalmarkt square in Leiden led to repeated police interventions. A year later, Eurodusnie activists threatened to disrupt Queen Beatrix's visit to Leiden. During these years (1998-2000), Eurodusnie gained international notoriety for 'pieing' neoliberal politicians such as Frits Bolkestein (later to become European Commissioner for Internal Market and Services) and Finance Minister Gerrit Zalm.

In the years that followed, however, the group took a different direction and refocused its energies on building alliances outside the radical subculture, which one of the Eurodusnie activists denounced as a 'squatted ivory tower'. ${ }^{19}$ In 2005, the group dropped the self-described term of 'anarchist collective' and later changed its name to Vrijplaats Koppenhinksteeg. In a contribution to the anarchist monthly Ravage, one Eurodusnie activist characterised the move away from traditional radical-left politics as an attempt to 'connect with people through initiatives and projects that actually are helpful to them, that surprise them and appeal to the imagination. ${ }^{20}$ The collective thus developed from an activist group into a social and cultural centre.

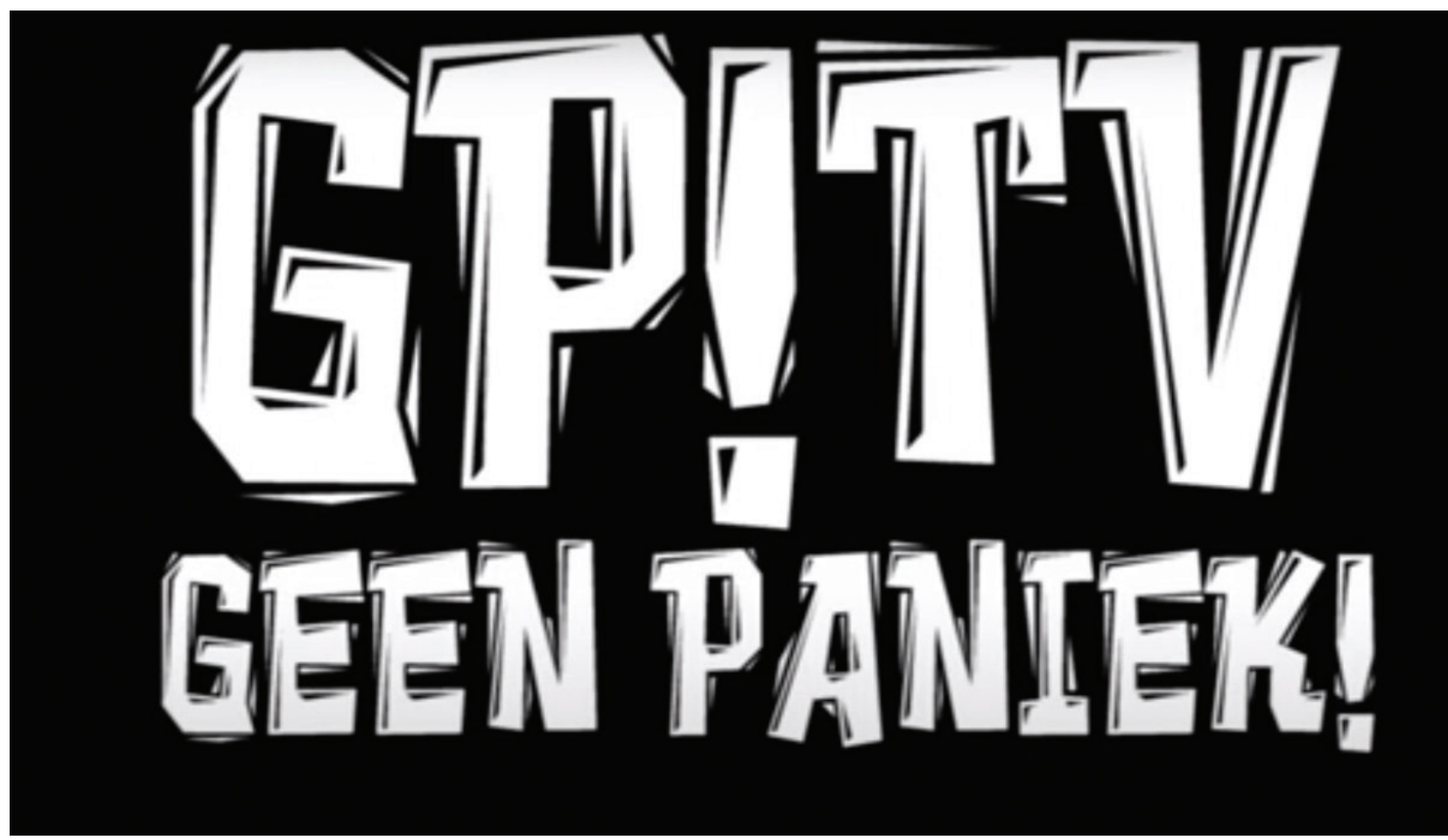

Figure 3. “Op bezoek bij de Weggeefwinkel en Linkse Kerk” (2008). Eurodusnie opened the first 'weggeefwinkel' (free shop) in the Netherlands. This self-produced video introduces the shop and shows how it works and who uses it. 
Despite the changing politics of the group and significant support in the city and from the municipal council, the group was evicted from its central location in 2010. By 2007, the group had already decided to leave the Boerhaavelaan squat to allow construction of a new school building there, and in 2010, the police evicted the Koppenhinksteeg complex after the city government decided to repurpose the building for high-end shops and apartments. After a lengthy campaign, the city government sold an old, monumental and derelict canning factory on Middelstegracht to the group for the symbolic amount of one euro. Many of the group's original activities are now organised there. ${ }^{21}$

Eurodusnie's attitude towards the media was ambiguous. On the one hand, the group tried to be media-friendly, by assigning members the role of spokesperson and handing out contact details. On request, journalists were given a tour of the buildings. In addition to publishing its own magazine, the group ran a website. The group soon found that local media could at times be fooled - for example, by announcing a famous speaker or band that was in fact not scheduled to come. ${ }^{22}$ Activists also exploited the fact that Leiden's free local weeklies did not scrutinise press releases and often would print them in full, thus providing Eurodusnie opportunities to spread its message at virtually no cost. Such actions gave the group a sense of power and initiative when it came to the media.

At the same time, the group soon established that their politics were of little interest to the mainstream media. ${ }^{23}$ Actions such as the occupation of the Ministry of Finance were largely ignored, while the 'pieing' of prominent politicians generated attention for the action, but not for the politics behind it. In March 1999, the group stated that the media was not capable of producing anything beyond 'easily digestible background reports'. ${ }^{24}$ The group concluded:

Behind the policies of our political and economic opponents lies a broadly shared consensus (...) it is not easy to get people to question that consensus. In fact, it takes a great deal of courage, patience, work and perseverance. ${ }^{25}$

Thus, one of the group's members stated that the goal should be to 'create open situations in which people start to think for themselves again instead of simply consuming. ${ }^{26}$

With its analysis of the workings of mainstream media and how to respond to it (i.e., with spectacular actions or tactics that disrupted this logic), Eurodusnie placed itself in a long-standing 
international tradition. Activists and social movements from the 1960s onwards developed an extensive array of culture jamming and 'communication guerrilla' tactics, which include the organisation of happenings or agitprop performances in public spaces, sniping and billboard banditry (slightly altering advertising slogans in order to give them entirely different meanings), producing fake versions of mainstream newspapers or official documents, and radio and television piracy. Eurodusnie, however, could draw on historical examples such as the Amsterdam Provos or the New York Redstockings for inspiration, as well as contemporary groups working within the alterglobalisation movement, such as the Tute Bianche. ${ }^{27}$ The group's decision to publish its own newspaper (Dusnieuws) was partly prompted by the mainstream media's biased reporting, although the early attitude of some Eurodusnie activists was summed up by an editorial calling on supporters to not only read the magazine but also to act: 'You can also take a stone and smash the window of a well-known bank, the ideal combination of theory and practice. ${ }^{28}$

As well as Eurodusnie members being aware that local media could be 'fooled', they also felt that local reporters were fairer than national reporters. They even favoured certain local journalists, such as Wim Koevoet, whom they felt was sympathetic to their cause. ${ }^{29}$ However, in an interview, Koevoet claimed that his aim had always been to report in an objective fashion and avoid personal opinions:

I viewed the situation, as I still do, in a purely journalistic fashion. I thought it was important to report on remarkable, divergent things happening in and outside of the town. And Eurodusnie was different for sure. ${ }^{30}$

Leidsch Dagblad journalist Binnert Glastra responded to the suggestion that the local media could be tricked:

Of course they went about things in certain ways. And when something was up, they knew how to find you for information. But that is simply the way politics works, I wouldn’t call these tactics tricks. ${ }^{31}$

Counterposing the interviews with Eurodusnie veterans and (former) Leiden journalists seems to confirm Rucht's claim that social movements mainly dealt with the media through the strategies of 
Attack, Alternatives, Adaptation and, occasionally, Abstention. ${ }^{32}$ During Eurodusnie's existence, these different approaches led to continuous debate regarding the group's actions and the way in which they were reported in local media.

\section{Eurodusnie coverage: Framing contests}

Eurodusnie was an anarchist collective that devised spectacular action strategies to draw media attention to its cause, thus 'exploiting' the logic of mass media's functioning. Rucht would call this strategy Adaptation. Even so, Eurodusnie's actions were not always reported in a favourable way, prompting the group to respond. According to Rucht, they could do so through strategies of Attack and Alternatives, by either criticising the media or producing their own media. As the practices of Eurodusnie show that the strategies of Attack and Alternatives were often employed to influence the mass media, they can often be classified as part of Adaptation strategies. Even instances of strategic silences (Abstention) were often devised to influence mass media reporting. Eurodusnie's criticism of the media, for example, was mainly articulated in interviews with journalists of those same media outlets, or through letters to the editor of Leidsch Dagblad. In a similar way, Dusnieuws regularly printed articles that were later cited by Leidsch Dagblad, and this was sometimes part of an explicit media strategy of Eurodusnie. In the following section, we analyse a number of representative cases of Eurodusnie interacting with local media, in order to modify Rucht's quadruple A model.

\section{Animal Rights Week, 1998}

The Animal Rights Week of 9 to 15 April 1998 illustrates how Eurodusnie combined the media strategies of Adaptation, Attack and Alternatives in its attempts to gain favourable media attention. The Animal Rights Coalition organised the action week, while Eurodusnie hosted it by offering its spaces. Eurodusnie activists also played an important role in the activities, which ranged from lectures and debates to the picketing of the Harderwijk Dolfinarium, ${ }^{33}$ the Leiden biotech company Pharming (which had recently gained prominence for being the first to clone two calves) and two local McDonald's restaurants. ${ }^{34}$ The actions were explicitly designed to draw media attention, and in that sense they are an instance of the activists' adaptation to mass media logic.

One action in particular garnered attention, albeit not too favourable. During the picketing of one of the McDonald's restaurants, a scuffle ensued, with the activists subsequently entering the 
premises. According to Leidsch Dagblad, 'food was violently swept off the tables, as stunned customers watched, plants were torn out of their pots, signs were torn off the wall and the glass door was damaged'. ${ }^{35}$ The newspaper cited two furious liberal councillors, who called for the eviction of Eurodusnie from its two (squatted) buildings. Eurodusnie's immediate response illustrates how instances of Attack rather fit under the banner of Adaptation, since they exploited the logic of the mass media. Eurodusnie accused Leidsch Dagblad of being biased and demanded a rebuttal. In a subsequent interview, a female member of Eurodusnie denounced how the newspaper had ignored the fact that activists at the second restaurant had been completely non-violent. These activists had baked pancakes in front of the restaurant, inviting prospective McDonald's customers to consider vegetarian alternatives to hamburgers. ${ }^{36}$

In a similar way, the non-violent picketing at the Dolfinarium did not receive media attention, but Leidsch Dagblad did report on the picketing of Pharma, which ended with a small altercation with the police. ${ }^{37}$ In this instance, however, the newspaper report was critical of the police rather than of the activists, and consequently, Eurodusnie did not respond or attempt to alter the media frame.

Eurodusnie also tried to counter negative media framing through letter writing. In response to negative reporting, the group sent a letter to the city government explaining its political motivations, with a duplicate to Leidsch Dagblad. ${ }^{38}$ When a Leidsch Dagblad reader denounced the 'vandalistic actions' at McDonald's, Eurodusnie replied with a letter to the editor, calling the reader's accusations 'prejudiced and unfounded'. ${ }^{39}$

\section{Queen's Day, 2000}

A second case illustrates not only how Eurodusnie used Attack as part of its Adaptation strategy, but also how it used Alternatives and strategic media silences to exploit the logic of the mass media. As well as using its own media to inform its direct circle of supporters, the group interacted with other media, as their Dusnieuws articles were cited in Leidsch Dagblad. Furthermore, they capitalised on the media's eagerness for news by creating and exploiting a news vacuum.

In January 2000, the municipality announced that Queen Beatrix would visit Leiden on 29 April 2000, as part of national holiday festivities (Queen's Day). Although local authorities were excited, they also feared counter-actions by Eurodusnie, which had earned an infamous reputation for 'pieing' various politicians in the previous months. Would Eurodusnie take the visit as an occasion to mobilise for radical action? The media started to speculate on Eurodusnie's response. 


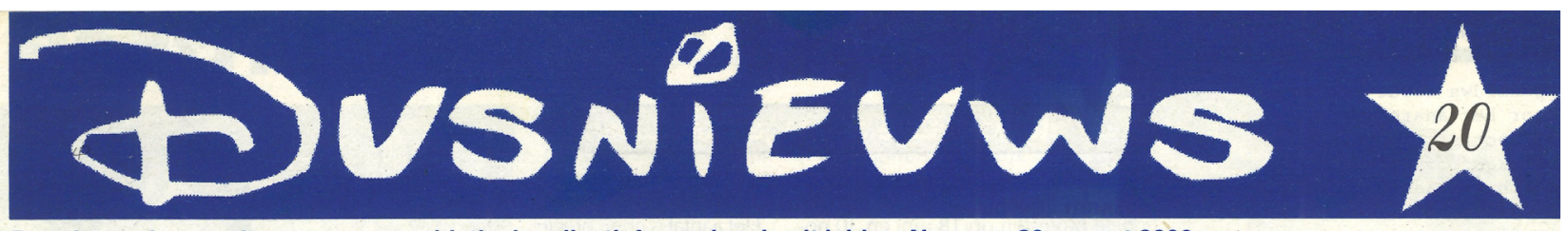

Dusnieuws is een uitgave van anarchistisch collectief eurodusnie uit leiden. Nummer 20, maart 2000
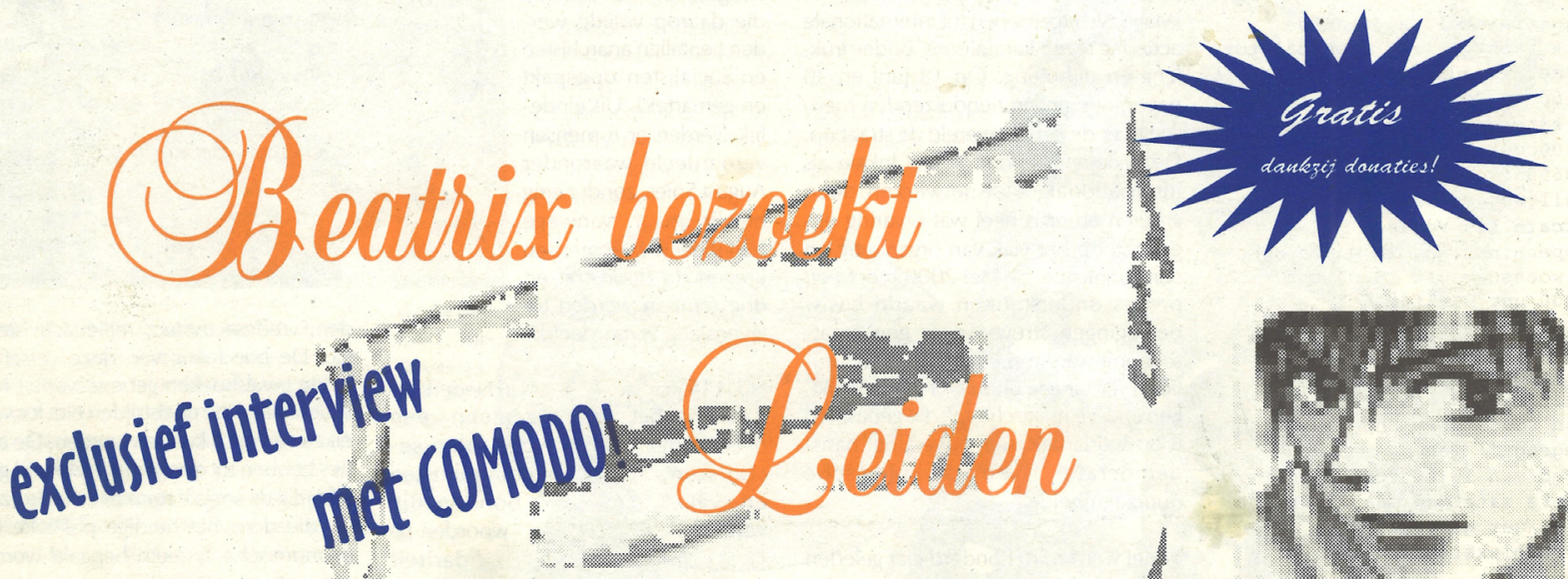

(4)

In het knusse, bruine cafe De Âlbatros in Katwijk ontmoet uw verslaggever van Koekoeroe Reed loen lid van het Comite Mars op de Oranjes (COMODO) voor een exclusief interview. COMODO is va:nplan een "Mars op de Oranjes" te houden op Koninginnedag, op 29 april in Leiden. Hun Manifest inc ysief eisenpakket is inmiddels bekend; maar voor de rest blijft COMODO een tamelijk schimmige club. Hopelijk schépt dit interview wat meer duidelijkheid.

Wat is COMODO nu precies? Is breker, Ininginnedag politiek maken. het niet gewoon een dekmantel voor EuroDusnie?

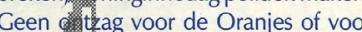
de sta. Wij zien ons verzet op Koninginned ook als onderdeel en ondersteuni voor 1 mei, internationale aktieda tegen het kapitalisme.

Dus niet, anders hadden we het wel Beadusnie genoemd. COMODO is wel degelijk een landelijke organisatie, waar mensen uit meer dan tien verschillende steden aan meewerken. We wisten we dat iedereen meteen aar EuroDusnie zou denken: de Mars gaat nu eenmaal in Leiden plaatsvinden. Vandaar dat we alle betrokkenheid van EuroDusnie bi COMODO wilden ontkennen. Maar goed, ik kan je wel vertellen dat een

paar mensen van EuroDusnie ook bi het Comite zitten Verder vind ik helemaal niet dat we een schimmige organisatie zijn. Onze ideeën zijn bekend we hebben een website, een emailadres, binnenkort houden we een kort infotoertje, duis mensen kunnen alles over ons te weten komen. Onze ach ternamen en solinummers zijn inderdaad niet bekend ํำaar dat is alleen interessant voor de politie.

$\mathrm{Nu}$ is iedereen natuurlijk enorm benieuwd naar wat er gaat ge beuren op 29 april. Dus vertel op: wat gaat er gebeuren?

Het wordt een krachtige manifestatie tegen het Koningshuis en tegen alles waar dit Koningshuis op koninginnedag symbool voor staat: het ontzag voor de nationale staat en de kapitalistische orde. K@ilikinnedag heeft dus een politiek karakter, ook al zien veel mensen het als een dag om lekker vrij te nemen en wat te drinken etc., waar natuurlijk niels mis mee is. COMODO is juist voo meser vrije dagen. Maar we willen de consensus over Koninginnedag doorHet is een heel verhaal, waar mensen bijvoo beeld ons Manifest op kun-

bijvoo neeld ons Manifest op ku over de monarchie in deze Dusniěuws, red.). Over de vorm van wat we willen doen: de ontwikkeling hier1. nog steeds in een dymaar het gaat de moeite waard worde $n$ COMODO c. ijft trouwens niet 4. traal voor wat er op d. ze dag moet gebeuhn, laat dat duidelijk in. Als mensen zelf een leuke stunt besenken dan juichen - dit natuurlijk toe.

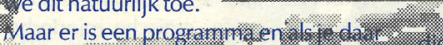
wees dan om elf uur in Leiden. Je kunt ook al een dag eerder komen voor een opwarmend feestje. Hou verdere mededelingen in de gaten! Er komt trou wens ook toffe muziek, want we willen er ook een leuke dong maken.

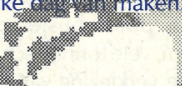

KOMEN ER RELLEN?

Welnee. Denk je nou echt dat we rellen willen organiseren met tiêduizenden oranjefreal sis en bijna duizend agen-

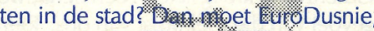
net als de Orabi: $860 \%$;r geteden, op de vlucht naar Engeland? Verthalen over rellen en verstoringen worden alleen verspreid door de Telegraaf enzo, dat lezen mensen graag.

Maar die guillotine van jullie, $d$. spreekt toch boekderen?

Dat zie je verkeerd. De guillotine is een internationaal symbool voor de antimonarchistische bewe-
ging; de Movement monarchistische bewe-
ging; de Movement against the Monarchy in Enge and heefthem bijvoorbeeld ook als
mascotte. Die hebben er een op wieltjes. Natuurlijk willen we dat ding niet echt gebruiken. we zijn namet:k principieel tegen de doodstra: Het is gewoon een sterk en duídelijk symbool tegen het Koningshuis. Het maakt duidelijk Idat we met niets minder dan volle(1ige afschaffing genoegen nemen. En wo trouwens, onze mascotte is heel wat

beter dan die van het Koninoshuis! Zo'n stomme leeuw met een zwaard in $z^{\prime} n$ poot. Dat slaat toch nergens op, er zijn niet eens leeuwen in Nederland.

Veel mensen zullen het nogal zinloos vinden om ten strijde te trekken tegen het Koningshuis. Zijn er nou echt geen belangrijkere dingen om je druk om te maken? En wat betekent dat Koningshuis nou helemaal?

Natuurlijk zijn er andere, ook meer dringende zaken, waar op een andere manier politieke strijd om gevoerd wordt. Maar het gaat niet alleen om het Koningshuis zoals ik je net al zei, ook over onze kapitalistische orde die op ko- ninginnedag gelegitimeerd moet worden onder hysterisch oranjegeblaat. De Koninklijke familie zelf trouwens willen we zeker niet ontzien. ledereen doet maar of dat van die aardige, goedbedoelende mensen zijn. Als je iets op ze aan te merken hebt krijg je meteen het halve thid over je heen. Kijk maar thaar de kritiek die destijds op het Republikeins Genootschap is geleverd, of de reacties op het boek van historica of de reacties op het boek van historica 3anda van der Zee, die wat minder en die zich niet juichend over de Oranos uitlaten worden bijna beschouwd als lox dverraders. Nou, dan maar een land.

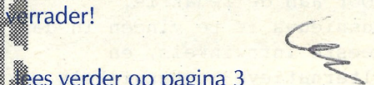

,
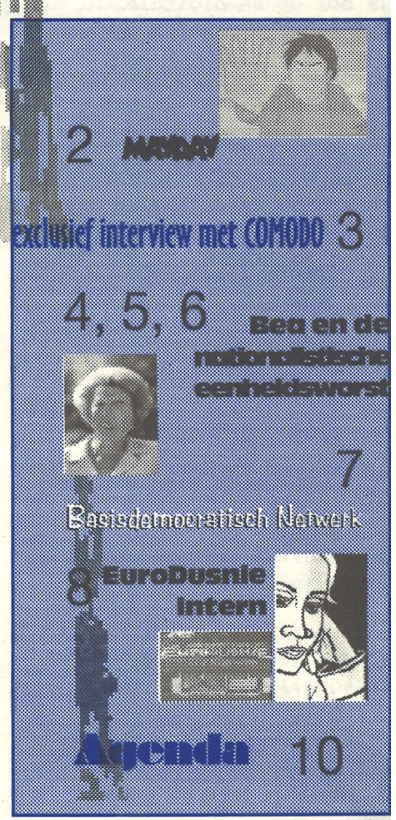

Figure 4. Eurodusnie activists responded to the queen's visit to Leiden in 2000 by announcing protest actions, which led to extensive speculation by the media on what these actions would entail. Dusnieuws 20 (March 2000). 
The municipality took extensive measures to ensure order and prevent obstruction by Eurodusnie during the queen's visit. This included closing off parts of the city and announcing a temporary ban on parking, sailing and even flying over the city. Leiden's mayor went out of his way to explain that these measures were standard procedure and had nothing to do with Eurodusnie, but Leidsch Dagblad stated: 'The simple sum Queen + Eurodusnie = emergency measures is easily made in Leiden and the whole of the Netherlands. ${ }^{40}$ Eurodusnie played into this controversy by claiming that their group had been subjected to undercover surveillance, forcing both the mayor and the Minister of Justice to deny these claims. ${ }^{41}$ Eurodusnie's plans remained unclear, while the authorities' fears of escalation became a central media topic.

Eurodusnie strategically exploited the anxieties of the authorities and the media by first refraining from comment. In their own magazine, Dusnieuws, Eurodusnie attacked the mainstream media for its focus on spectacular actions, calling journalists 'newshawks' and stating: 'In these moments, you realize what the ladies and gentlemen of the media are about, namely lowbrow spectacle and scoops. We still have to welcome the first journalist who comes to us for an in-depth discussion of our criticism of for example the European unification. ${ }^{42}$ In another article, an activist stated: 'Stories about riots and disturbances are only spread by the [conservative tabloid] Telegraaf etc. because people like to read that. ${ }^{43}$

In a second stage, Eurodusnie started to tease the media with secretive plans speculated on in its own magazine. Thus, a Comité Mars op de Oranjes (Committee March on the House of Orange, COMODO) was founded, of which Eurodusnie was a member. The committee stated that it was planning 'something big', but also stated in an interview with Dusnieuws: 'Do you really think that we are going to start a riot when we are surrounded by tens of thousands of monarchist freaks and thousands of police officers?'44 Eurodusnie thus attempted both to evoke and to dispel fears of escalation, using its own media to maintain control of what they wanted to have published while also using it as a means to interact with other media. Indeed, the interview was quoted in Leidsch Dagblad. ${ }^{45}$

Eurodusnie thus tried to further a media frame of overreacting authorities, claiming that nothing legitimised such overreaction. However, Eurodusnie also did not want to be seen as a completely innocent organisation. Its political and media-related practice was grounded in contentious action. This led the group to balance threatening imagery with fierce attacks on reporting that suggested the group was actually violent. 
It seems, however, that Eurodusnie overplayed its hand with the COMODO interview. Leidsch Dagblad concluded that Eurodusnie was not out for confrontation and changed its interests accordingly. At the beginning of April, Eurodusnie tried to up the ante by placing a self-made fake guillotine in front of one of its two buildings. The action was clearly provocative, and in an interview in Dusnieuws, a COMODO member anticipated the question as to whether the guillotine implied violent action: 'You got it all wrong. The guillotine is an international symbol of the anti-monarchist movement.' Jokingly, the activist added that they were not planning to use the guillotine: 'We are, after all, against the death penalty. ${ }^{36}$ Despite the symbolic and provocative nature of the action, it received little attention from the media. Obviously, the fear of escalation had subsided, and Leidsch Dagblad was no longer convinced of the risk of violent escalation. Eurodusnie's balancing act of alternately evoking and dispelling fear of escalation had lost its traction in other media.

This was shown all the more clearly on the day of the queen's visit. Instead of a confrontational action, Eurodusnie organised an anti-monarchist street party outside the town centre. Its centrepiece was a play in which an actress, dressed up like the queen, was brought to justice for her crimes against the population, and as punishment, she had a pie thrown in her face. The action received a small mention in the newspaper. ${ }^{47}$

Remarkably, Leidsch Dagblad kept focusing on (fears of) violent escalation in its reporting on the queen's visit, even after the event had passed peacefully. In December, Leidsch Dagblad published a reconstruction of the authorities' preparations, criticising the extravagant security measures. ${ }^{48}$ Eurodusnie was only mentioned briefly - as the reason for the measures - but the group's goals, plans and, ultimately, festive and non-confrontational activities were not mentioned. Leidsch Dagblad focused, above all, on (threats of) violence, while more peaceful activities gained much less space. Eurodusnie had responded creatively to these fears, using Attack and Alternatives strategies as part of an overarching Adaptation strategy.

\section{Reclaim the Streets \& People's Global Action, 2002}

Eurodusnie would regularly respond to negative frames in Leidsch Dagblad by sending letters to the editor. However, if frames were supportive, the group would react with strategic silences. Eurodusnie did not respond to all media reports in Leidsch Dagblad, as is illustrated by two cases described below.

In June 2002, Eurodusnie activists protested a restraining order for youths, alcoholics and homeless people at the monumental Burcht park in Leiden's city centre by organising a 'Reclaim the Streets' party. Around midnight, the police used force to break up the party. One Eurodusnie activist 
was forcefully arrested and maltreated. Fellow activists subsequently took pictures of his injuries, which they handed out to city council members. Several councillors requested a thorough investigation, while others held that the police intervention had been justified and fair. ${ }^{49}$ Overall, the reporting by Leidsch Dagblad was factual, although they did mention that the activist was not known for being violent. At one point, the newspaper questioned the claim of the police that the activist had been beaten with a baton only once, quoting the latter: 'He [i.e., the police officer who hit the activist] cannot make both my arms, my legs and my back turn black and blue with just one blow. ${ }^{50}$ As Leidsch Dagblad's coverage seemed to support one of Eurodusnie's main claims, they did not challenge the reporting.

In a second case, Eurodusnie only responded to one report. This happened in the wake of Eurodusnie's hosting of an international conference of People’s Global Action in September 2002, to discuss 'a sustainable, peaceful and social alternative to capitalism'. ${ }^{51}$ The international participants would be accommodated on a provisional camping site next to the concert and convention centre Groenoordhallen. This provoked criticism from business owners and conservative city council members, who feared disturbances and squatter actions. In response, Eurodusnie gave a newspaper interview: 'We are not going to squat that terrain. What are we to do with such a plot of land and a few small pillboxes? ${ }^{52}$ However, when the conference was over and Leidsch Dagblad questioned its success and the number of participants, ${ }^{53}$ Eurodusnie refrained from responding.

\section{Eurodusnie's pie-throwing campaign and its legacy, 1998-2005}

The most spectacular and notorious campaign of Eurodusnie was its 'pieing' of three politicians between 1998 and 2000.54 In 1998, Dusnieuws advocated pie-throwing, confidently stating that such actions 'will receive much media attention' and thus provide a platform on which to publicise the politics of the group: 'Everybody wants to know why a pie has been thrown; you can thus easily push the political story behind your action. ${ }^{55}$ However, Eurodusnie would soon become disappointed with the action's political potential and the media's responses, as well as the group's limited control over the media's framing of the action.

Eurodusnie activists threw their first pie in April 1998, in an ironic celebration of the group's first birthday. Their target was the mayor of Noordwijk, where Eurodusnie activists had attempted to squat a hotel but were evicted on the mayor's orders. On 5 April, fifteen Eurodusnie activists visited the mayor's residence, well equipped with festive paper hats and two pies. The mayor was led to think that he was given the pies, but instead had them thrown in his face. 
On the following day, Leidsch Dagblad published a photo of the mayor with a pie in his face, and this image was taken by the Eurodusnie activists themselves. ${ }^{56}$ According to Eurodusnie veteran Marco van Duijn, Leidsch Dagblad was initially hesitant to publish the photo, claiming that it was unethical to print a photo produced by the activists, but it yielded when Eurodusnie threatened to give the photo to another newspaper. According to Marco van Duijn, the event showed the group's influence on the media: 'We used the media constantly for our own purposes. ${ }^{57}$ A fellow veteran member had this retrospective assessment: 'A pie action is only successful when it attracts media attention. So, yes, Leidsch Dagblad was simply being used. ${ }^{58}$ Even so, Leidsch Dagblad's report mainly quoted the furious mayor, who called the activists 'scoundrels', stating: 'I do not want to waste more words on this. C'est tout. 59

At the end of 1998, the Werpgroep TAART was formed. ${ }^{60}$ In December, this group pied the leader of the liberal party, Frits Bolkestein, at the start of a lecture at Leiden University. According to the group, the pie was thrown 'on behalf of the "victims" of neoliberalism'. ${ }^{61}$ Leidsch Dagblad again published a picture, which led to a fierce response from one of the readers. In a letter to the editor, he stated that by giving the activists a voice, Leidsch Dagblad was 'responsible for the pie in the face of Mister Bolkestein'. ${ }^{62}$ Leidsch Dagblad countered his argument by stating that they did not make the news, but merely reported it: 'The newspaper is independent and can barely influence events.' ${ }^{63}$

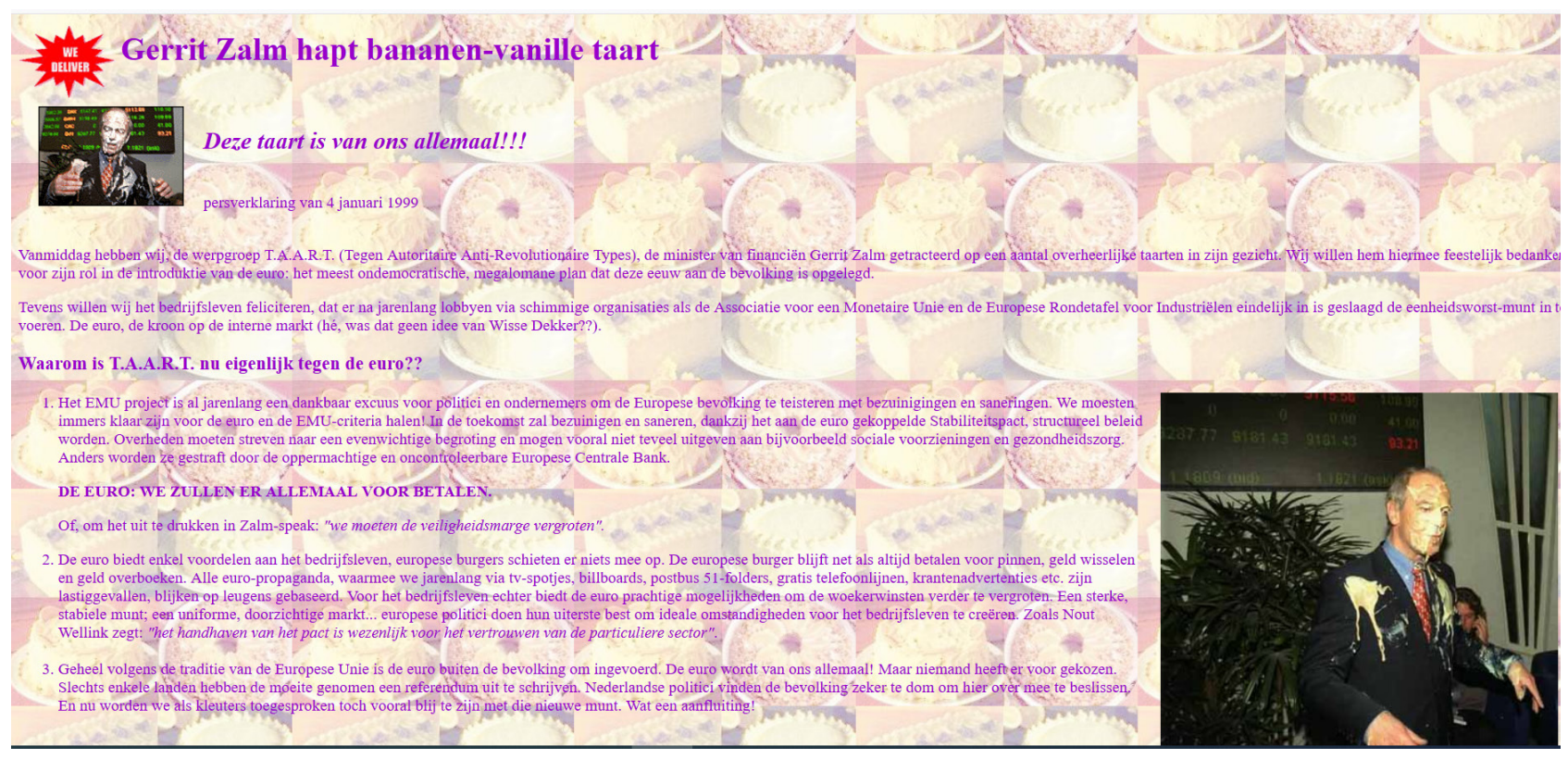

Figure 5. Although the 'werpgroep T.A.A.R.T.' is no longer active, its website is still online and can be viewed at http:// www.members.tripod.com/ taart/. 
The third action of TAART, however, showed the limits of control over the media. In January 1999, the group cooperated with the commercial television programme Gekkenhuis ('Mad House', RTL 4) in order to throw a pie in the face of Minister of Finance Gerrit Zalm during the official introduction of the euro as an accounting currency in the Netherlands. According to two Eurodusnie veterans, the programme had contacted Eurodusnie and proposed the action. The Eurodusnie activists saw an opportunity and decided to take up the offer. With the help of the television crew, the activists gained access to the Amsterdam Stock Exchange, where the official introduction of the euro took place. When Zalm came forward to deliver a brief speech, one of the activists came to the front, hurled the pie in his face and yelled: 'This one is from all of us!', referring to the campaign slogan that introduced the euro in the Netherlands ('The euro will belong to all of us').

The action received international attention, but in the Netherlands, Eurodusnie suffered a heavy backlash in the media. Two activists were invited to the studio of Gekkenhuis, but to their surprise, the presenter had also invited the chairman of the youth organisation of Zalm's liberal party (Volkspartij voor Vrijheid en Democratie [People's Party for Freedom and Democracy], VVD), who strongly denounced Eurodusnie’s actions. The presenter subsequently introduced a psychologist who spoke about the 'potentially considerable psychological damage' that could be caused by 'pieing' someone. The activists' opportunity to reply was cut short and the programme ended with a reprimand by the presenter. The programme thus gave voice to Eurodusnie's opponents. In a critical analysis, the progressive national weekly Groene Amsterdammer concluded: 'Their attempts to use the media to spread their message have turned against them: no one talks about the ideas behind the actions. ${ }^{64}$

Eurodusnie judged the third action a failure, stating in Dusnieuws that they would discontinue the campaign: 'Any person who still dares to use the word pie will be thrown out of the building!' 65 The group was self-critical, stating that 'the media politics of werpgroep TAART was not very well thought through'. However, the main criticism was directed at the mass media, which was only interested in 'spectacle' and 'soundbites', but not in the politics driving the action. One member stated in Dusnieuws:

If you look at the media reports, they boil down to an image of crazy people who organise terrorist actions and damage the image of the minister because, for some reason, they are against the euro. ${ }^{66}$ 


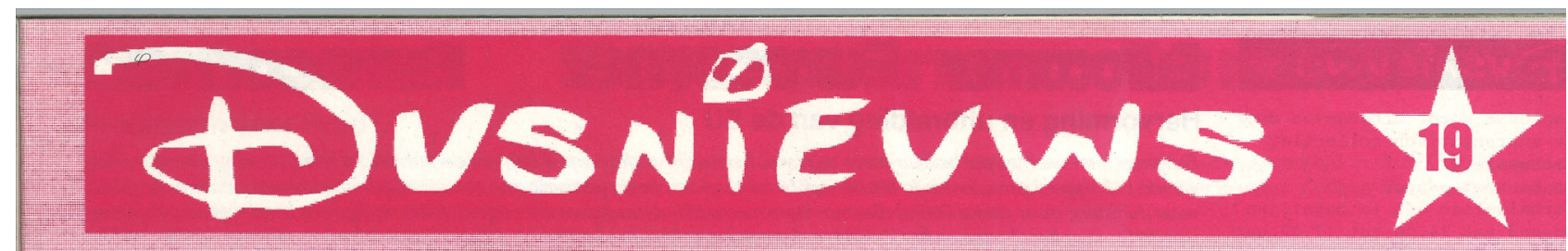

Dusnieuws is een uitgave van @narchistisch collectief EuroDusnie uit Leiden. Nummer 19, uitgave februari 20

Eind januari kwam er een email binnen bij EuroDusnie voor aktiegroep T.A.A.R.T. Agent Apple van the Blotic Baking Brigade (BBB) deed Nedertand aan, alvorens hil naar een Earth First gathering ging in Londen. Dit was voor ons een mool moment om recepten uit te wisselen en eens even te kijken hoe het staat met de pie movement in Amerika. Op hetzelide moment dat will een gesprek hadden met Agent apple zijn er 3 personen getaart op een Canadese conferentie over genelisch manipulatie.

\section{The Ple Is the limit!}

Agent apple is zell alktief bi een anar activisten in de voortuin van dezelide perchistische organisatie in San fransisco, soon cen pop gemaakt. Ze belde aan en deze organisatie houd zich o.a. bezig toen deze persoon de deur open deed

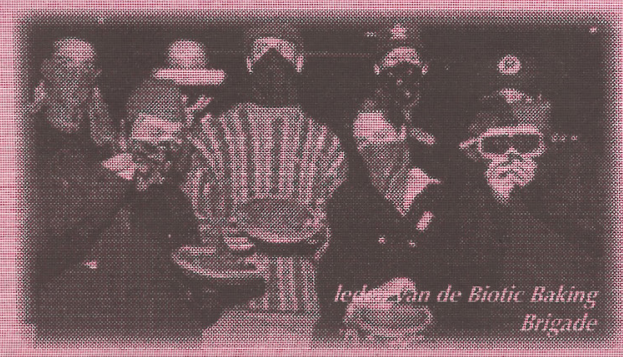

verd de pop in de-fik gestoken Deze persoon heeft een tijd lang niets meer van zich laten verne men.

In een tweed geval ging het om de directeur van Monsantodieeen bezoek brach aan San rransisco Het idee was om

in deze taart een Bombs, dierenrechten en last but not 'roundup', wat Monsanto ontwikkete least taarten. Wi hebben een aantal vra- had en wat vo gens hen heel onschade gen aan hem gestełd waar IA.A.R.J ook lik zou zijn. Maar dat werd op het taat- ste momen nagedacht Sommige mensen verdienen geen lowif toch maaraf heeft: soblazen $*$ is insom matreen steen teoen hethoofd. Wat BBBer mige geval wel deden Ien taarten gooien niet een te ludiek- was het volgende: nadat de directeur met aktiemidde?

* Hoe ga je om met de media?

* Weegt de publieke opinie zwaar mee als jullie een doelwit witzoeken? lefoentie aepleood naar hot hoofdlkantoo van Monsanto waarin werd gerneld dat

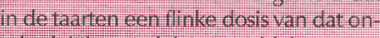
schadelike verdelgingsmiddel zat verIs in sommige gevalten taat gooten niet werkt. De mensen bii Monsanto flipten eer te tivilet aktiemidde? - compleet en hebben de verdere bezoe

Sommige personen die verdienen genen van mensen van Monsanto dan San taant maar die verdienen een steen tegen het hoofd. Ook hier liepen zil reget-

matig tegenaan. Hoe ga je om met mediath Nedertand De-cerste keer dat a hier tegenaan tie- was het zo dat er vooral gekeken werd pen was met een professor die zich al nar het aktiemiddel zeff en niet naar de 15 jar bezighield met vivisectie en deze persoonzou centezingkomengevenop - In het begin was dit ook met de Biotic deze getegenheid werden een tweetal Baking Brigade het geval: Fr werd alleen taarten bereid met een bodem die zo naar de aktie gekeken, en vooral de wat hard was als steen progressievere meen een bloedrode De verdere bezoeken van dialiethet aiweten. vulling ef op. Wil Le Zij deden op een het taartengoni Monsanto danSan francisco zeer negatieve ma bestand werd een werden afoelast nier verslag van de persoon gezocht - taatlakties. Om dil dieech goele werly- - te voorkomen wordt arm had. Hievoor kwamen ze terecht nualles in eigen hand genomen. Er wordt bij een voormalig pitcher werper bi zelf een video gemaakt met interviews honkbal). De professor werd geraakt tij- en beelden van de aktie die naar tv zen dens zijn lezing en sloeg zo hard achter- ders wordt gestuurd. Daamaastwordt bij overvan de klap van detaart clathij bijna jedere vadag vin een knant, nadio of tv

onderuitging, hi: werd daama nogmaals voor een interview gekeken wat er mee

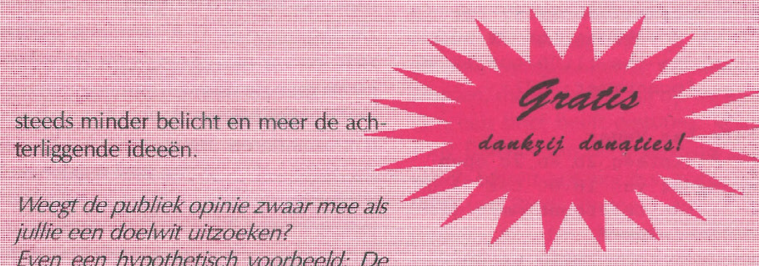
doew wit uizoeken

Even een hypothetisch voorbeeld: $D$ Nedertandse kroningin kamt nat lei den. Zil is erg geliefd bil het wolk'. Zou dat een reden zïn voor jullie om niet toe te shan?

In principe moet je je niets aantrekken van de publieke opinie als je maar heel zeker van je zaak bent. Als je je iets zou aantrekken van de publieke opinie dan zou je in een rijtieshuis moe ten gaan wonen on ie mond houden. Maar het is wel iets

waar je $m e e$ moet den. Bij d e? burgermeaster

Fiansisco had $=$ denwi

hier lang over na ge dacht. Deze persoon be nadrukt in elke toespraak die hï geeft dat hij nog sa men met Martin Luther King in demonstraties heeft mecgelopen. Maar nu is he een ongelooflijke rechtse klootzak die pleit voor dezelfide dingen als waar

Coebbels voor pleitte in de Tweede We reldoortog

Deze aktie zou als het niet goed opge pikt zou worden door de media afge daan kunnen worden als een racistische aktie. Een drietal taarten troffen de burgermeester in zïn gezicht. Eên van Fili bodyguards zorgde enoor dat hi

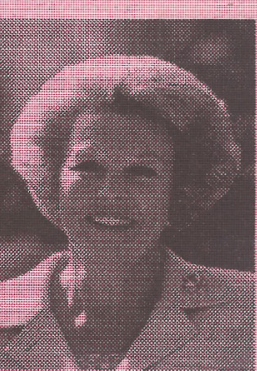
truitolde zijn enkel verzwikte wat later de drie taarten gooiers(sters) werd aangerekend. Eên van de bodvguards werd 20 agressief dai hij bij een taartgooiers een sleutelbeen brak Alle drie de personen werden gearre teerd en moesten voorkomen. In de kranten was veel aandacht voor $h$ "gewelddadige" karakter van de akd matar verbazingwekkend werd er or veel aandacht besteed aan de motiv tie van de actievoerders, In de recht zaal waar ze te horen kregen dat. een halfjaar de cel in moesten, $\mathrm{kr}$ gen ze ook nog de ruimte om h verhaal te doen waardoor alle aa wezigen nogal geschokt werden Ze hieiden een betoog over de fa cistische ideeën van de burg meester hoe San Franscico da lozen en daklozen centra viii

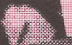
zen en daklozen centra vii
maken. Foen ze hun betor hadden beeindigd waren aanwezigen vrij gescho - Dat waren ze helemaal toc dat delen van toesprakend de burgermeester had voo gedragen letterliik terug vinden waren in toesprake van Coebbels in de Tweec Wereldoorlog. Helaas wase niet genoeg om viljgesproke te worden:

Maar ze waren niet treurige zeiden tegen alle taartgooiers in wereld: "let a million pies fly!

Kiik eens op interm Kijk eens op interm
www.asis.com of su mw.dsl.nl/feurodusnie en kilk bij $f$ AART-link

Inhoud

$\div 2$

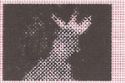

Eurocorner

4

De tegencultuur van links?

5: Gratistrein; Wereldwijd.

6: Attac; Intern

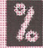

8

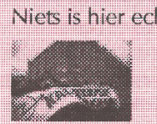

9: Derde wes

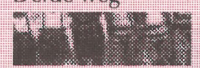

Figure 6. In the collective's self-published magazine Dusnieuws, the group reflected on the intended and realised effects of pieing prominent politicians. Dusnieuws 19 (February 2000). 
In a retrospective, Dusnieuws stated: 'Eurodusnie and TAART have cooperated with the media on several reports and articles. Overall, the experiences have been negative.' The supposed reason was the media's focus on 'spectacle and appearances' ${ }^{67}$ It was one of the reasons why the Leiden activists quit their campaign.

Even so, the campaign created a lasting legacy. In February 2002, two years after the last pie was thrown by Eurodusnie activists, another group 'pied' the populist politician Pim Fortuyn. ${ }^{68}$ Two months later, when Fortuyn was shot and killed by a radical environmentalist, many interpreted the pie-throwing action as a build-up and precursor to the murder. As Fortuyn's murder was linked to 'pieing', and pie-throwing was linked to Eurodusnie, Fortuyn supporters responded to the assassination by attacking both locations of Eurodusnie and smashing the windows ${ }^{69}$ In 2005 , during Eurodusnie's referendum campaign against the European Constitution, a Leidsch Dagblad journalist refuted the group's democratic credentials by referring to its pie-throwing campaign of $1998-99.70$ Eurodusnie responded by stating: 'Let us finally stop talking about those pies and instead focus on the Constitution.' ${ }^{71}$

Eurodusnie initially had high hopes for their 'pieing' campaign, expecting it to garner attention for the action and for the group's politics. When it turned out that the media was mainly interested in the former, the campaign was discontinued, but it had a lasting influence on their reputation, showing the limits of their influence on the media and their reporting.

\section{Conclusion and discussion}

Activists and journalists need each other, but for different reasons. Their divergent interests make their relationship a tense one and may even lead to clashes. Eurodusnie made efforts to be represented in a generally favourable way and to get their message across. The Eurodusnie case demonstrates how frames and counter-frames were negotiated through the interaction between protesters and the media. When news media coverage turned out negative, conflicts rarely concerned facts (e.g., about the extent of the damage done to the local McDonald's), but rather focused on frames. If news reports on Eurodusnie were unfavourable, Eurodusnie would often respond through letters to the editor, interviews or replies in its own publication, Dusnieuws.

Eurodusnie activists resisted being criminalised as anti-social and a danger to public order. In a careful balancing act, they promoted the counter-frame of concerned members of the local, national 
and global community, while at the same time strategically stressing their potential for disruptive action. ${ }^{72}$ A similar counter-framing media strategy has been employed by outlaw motorcycle clubs. In a 2017 case study, Burger and Koetsenruijter observed that Dutch outlaw motorcycle clubs would deny outright accusations of criminal behaviour, but reserve the right to be deviant, stating that, despite being rough around the edges, they were not criminals. ${ }^{73}$

Eurodusnie's biggest media coup in terms of coverage also highlights the inherent tensions of the activist-journalist relationship. The pie-throwing campaign was a success when measured in inches of newspaper columns, but it was mostly framed as sensational and disruptive. Unable to shift attention towards the message they wished to convey, Eurodusnie stopped pieing politicians.

Returning to Rucht's 'quadruple A' model of activist media strategies, we find that Eurodusnie's use of Attack, Alternatives and strategic silences (Abstention) can be regarded as part of their Adaptation strategy - i.e., they used the first three tactics to strategically 'exploit' the logic of mass media's functioning (Adaptation).

When Eurodusnie found itself at loggerheads with the local media, it seldom opted for full-out attack, and never moved beyond verbal rhetoric. The group did not - as German activists occasionally did - attack belongings of journalists or damage press property. ${ }^{74}$ They instead chose conventional communication channels and means to have their voice heard. They directly approached journalists, wrote letters to the editor, or used their own alternative media as an indirect means of conveying their messages to the mainstream media. The implication is that Abstention, Attack, Alternatives and Adaptation do not exist next to each other as different options, but rather overlap. In many cases, instances of Attack or Alternatives play into the logic of mass media and should thus be viewed as subsections of Adaptation.

Indeed, Adaptation dominated Eurodusnie's dealings with the local press. ${ }^{75}$ After staging mediagenic actions, they could lean back when the resulting coverage was framed favourably, or often successfully - contest negative frames. Rucht describes the relationship between social movements and the mass media as 'fragile and asymmetric', and assigns a decisive role to mass media, who 'basically select groups, issues, and actions according to their own criteria'. While movements that respect these criteria may receive positive coverage, those who ignore them 'are condemned to negative coverage or no coverage at all'. ${ }^{76}$ The Eurodusnie case study, on the other hand, suggests a more positive assessment of social movements' potential to influence the media and counter negative frames, and supports Manning's claim 'that it is possible in certain circumstances to contest or resist definitions offered by the powerful and to exert power in a counter direction. ${ }^{77}$ 
Rucht's quadruple A media strategies model originates, as does our case study material, in the era that predates the breakthrough of social networks and their affordances for activism. Present-day activists employ media strategies that differ according to their political orientation: left-wing groups appear to favour 'hashtag activism', right-wing activists rely on the extensive ecosystem of radical right alternative media and use disinformation and conspiracy theories more than their left-wing counterparts. ${ }^{78}$ In terms of Rucht's model, right-wing activists prefer Alternatives and Attack on the mainstream media (e.g., Lügenpresse, fake news media), simultaneously using Adaptation as they try to reach a wider audience by promoting their messages 'up the chain' from less to more established news media. ${ }^{79}$ All in all, however, the major role of the social networks' algorithms and the possibility of gaming them by employing bots or other inauthentic means of boosting the signal would necessitate a thorough revision of the quadruple A model.

Since most studies of activist media strategies have focused on larger urban centres, studying the relationship between Eurodusnie and Leiden's local news media sheds light on an environment where conditions may be qualitatively different. Are the generally amiable relations between Eurodusnie and local news media typical for small-town activism, as opposed to metropolitan movements? Interviews and earlier publications ${ }^{80}$ suggest that activists in towns such as Leiden felt treated more fairly by local journalists than by reporters of national news outlets, and that the national press covered local actions only as part of larger stories on a national level, specifically focusing on incidents and escalation frames. We may surmise that the potential for violent escalation is bigger in cities, and that events in the nation's capital will more easily make national news headlines, which in turn could incite activists towards more violent action. To verify such assumptions, however, more research is needed. Given the importance of media for social movements and the recent interest in social movements beyond the metropolis, new perspectives can emerge by systematically comparing the relations between local social movements and media in smaller towns and cities with similar relations in metropolises and capital cities.

\section{Notes}

1. The common currency agreed upon in 1992 and introduced on January 1, 2002.

2. Cohen studied the so-called Mods and Rockers of 1960s England as an example: Stanley Cohen, Folk Devils and Moral Panics (Routledge: London, 2011). 
3. Angela McRobbie and Sarah L. Thornton, "Rethinking 'Moral Panic' for Multi-Mediated Social Worlds," British Journal of Sociology 46, no. 4 (1995), 559-574; Willem Koetsenruijter and Peter Burger, "Mannen met een hobby: Outlaw motorclubs, nieuwsmedia en imagopolitiek," Tijdschrift voor Criminologie 59, no. 4 (2017), 376-392.

4. Dieter Rucht, “The Quadruple 'A': New Media, Citizens and Social Movements,” in Cyberprotest: New Media, Citizens and Social Movements, ed. Wim van de Donk, Brian D. Loader, Paul G. Nixon, and Dieter Rucht (London: Routledge, 2004), 25-48.

5. Edwin Amenta et al., "From Bias to Coverage: What Explains How News Organizations Treat Social Movements," Sociology Compass 11, no. 3 (2017), e12460; Rens Vliegenthart and Stefaan Walgrave, "The Interdependency of Mass Media and Social Movements," in The Sage Handbook of Political Communication (London: Sage, 2012), 387-398.

6. William A. Gamson and Gadi Wolfsfeld, "Movements and Media as Interacting Systems," The Annals of the American Academy of Political and Social Science 528, no. 1 (1993), 114-125, specifically 115.

7. Deirdre O’Neill and Tony Harcup, “News Values and Selectivity," in The Handbook of Journalism Studies, ed. Karin Wahl-Jorgensen and Thomas Hanitzsch (London: Routledge, 2009), 181-194.

8. Paul Manning, News and News Sources: A Critical Introduction (London: Sage, 2001), 14-18.

9. Rucht, "The Quadruple 'A'”.

10. Hanspeter Kriesi, Ruud Koopmans, Jan Willem Duyvendak, and Marco G. Giugni, New Social Movements in Western Europe: A Comparative Analysis (London: Routledge, 2015); Sidney Tarrow, Power in Movement: Social Movements and Contentious Politics (Cambridge: Cambridge University Press, 2011); Charles Tilly, Social Movements, 1768-2004 (New York: Routledge, 2004).

11. David Templin, "Beyond the Metropolises: Youth Centre Initiatives in the'Youth Revolt' of 1980-81 in West Germany," in A European Youth Revolt: European Perspectives on Youth Protest and Social Movements in the 1980s, ed. Knud Andresen and Bart van der Steen (New York: Palgrave, 2016), 67-80; Detlef Siegfried, “Urbane Revolten, befreite Zonen: Über die Wiederbelebung der Stadt und die Neuaneignung der Provinz durch die Gegenkultur der 1970er Jahre," in Stadt und Kommunikation in bundesrepublikanischen Umbruchszeiten, ed. Adelheid von Saldern (Stuttgart: Steiner, 2016), 351-366; Julia Paulus, “Eigensinn und Loyalität: Protest- und Mobilisierungskulturen in ländlichen Gesellschaften am Beispiel der politischen Emanzipationsbewegungen von Frauen (1970 bis 1990)," in Stadt-Land-Beziehungen im 20. Jahrhundert: Geschichts- und kulturwissenschaftliche Perspektiven, ed. Franz-Werner Kersting and Clemens Zimmermann (Paderborn: Schoeningh, 2015), 137-153; Sebastian Haumann, “Hausbesetzungen in Hilden 1980-1982: 
Protest im Kontext lokaler Ambitionen und Realität," in Mittelstadt: Urbanes Leben jenseits der Metropole, ed. Brigitta Schmidt-Lauber (Frankfurt am Main: Campus, 2010), 207-222; Heike Kempe, ed., Die 'andere' Provinz. Kulturelle Auf- und Ausbrüche im Bodenseeraum seit den 1960er Jahren (Konstanz: UVK Verlagsgesellschaft: 2014); Bart van der Steen, “Great causes and small places: Onderzoek naar sociale bewegingen in kleine steden en plaatsen," Stadsgeschiedenis 12, no. 1 (2017), 50-55.

12. Niek Pas, Provo! Mediafenomeen, 1965-1967 (Amsterdam: Wereldbibliotheek, 2015); Adilkno, Cracking the Movement: Squatting Beyond the Media (New York: Autonomedia, 1994); Rolf Amann, Der moralische Aufschrei: Presse und abweichendes Verhalten am Beispiel der Hausbesetzungen in Berlin (Frankfurt am Main: Campus, 1985); Michael Hermann, Hans-Joachim Lenger, Jan Philipp Reemtsma and Karl Heinz Roth, Hafenstrasse: Chronik und Analysen eines Konflikts (Hamburg: Verlag am Galgenberg, 1988).

13. This sample can be drawn from Leiden's digitised historical newspaper database "Historische Kranten, Erfgoed Leiden en Omstreken” at leiden.courant.nu, and it is part of a larger collection of Leidsch Dagblad articles on squatting in Leiden. Comprising over 700 articles, this larger collection was used to map 310 squatter actions in Leiden during the period 1970-2010. More information about this research project can be found on the website www.krakeninleiden.nl, maps.squat.net/en/cities/leiden and in: Charlotte Rooden, Merel Snoep and Bart van der Steen, "Who Are the Squatters? Challenging Stereotypes through a Case Study of Squatting in the Dutch City of Leiden, 1970-1980," Journal of Urban History 46, no. 6 (2020), 1368-1385.

14. We have made use of the personal archive of Marco van Duin, that contains all issues of the newsletter.

15. A brief discussion on the difference between local and national news reporting on Eurodusnie can be found here: M. van Wijk, “Landelijke en regionale kranten: één aanpak, verschillende uitkomsten”, http://www. krakeninleiden.nl/kronieken/landelijke-en-regionale-kranten-een-aanpak-verschillende-uitkomsten. A comparative analysis showed local news reporting to be often more neutral and focused on day-to-day events, while national news reports often approached Eurodusnie as part of larger developments (i.e., the rise and growth of the alterglobalisation movement) and were particularly prone to focus on perceived signs of radicalisation of the group or movement.

16. Gamson and Wolfsfeld, "Movement and Media as Interacting Systems”, 118.

17. Robert M. Entman, “Framing: Toward Clarification of a Fractured Paradigm,” Journal of Communication 43, no. 4 (1993), 51-58, specifically 52.

18. Camiel Donicie, "Eurodusnie. Over de idealen en praktijken van actievoerend Leiden," in Leven volgens je idealen. De andere politieken van huidige sociale bewegingen in Nederland, ed. Saskia Poldervaart (Amsterdam: Aksant, 2002), 160-196. 
19. Marco van Duijn “Repareer de samenleving,” Ravage, no. 1 (January 2000); Freek Kallenberg “De andere wereld laat op zich wachten," Ravage, no. 1 (January 2003).

20. Van Duijn, "Repareer de samenleving”.

21. Pim “Vrijplaats 4 jaar geleden ontruimd” (2014), https://vrijplaatsleiden.nl/blog/2014/02/26/ vrijplaats-4-jaar-geleden-ontruimd/.

22. Interview with Marco van Duijn, March 5, 2018. This practice had a longer history in radical movements. In the 1960s, the Amsterdam chapter of the socialist student group Politeia would use similar tactics to establish a continued presence in the media. In her autobiographical novel, Lisette Lewin recalls a conversation between two of Politeia's leaders: “"Have you read our announcement in [the student magazine] Propria Cures?” asked Leon. “I haven’t looked yet.” "Of course!” said Koos. "And, was it correct?” asked Leon, smoking his pipe. "Read it carefully. I bet they made some minor mistake or two. Demand a rectification. We must be mentioned each week.” Both laughed. (...) [Leon:] “Koos, next time, in the announcement for the FLN-meeting, we should mention that Sartre has been invited as speaker. That always draws attention.”' Lisette Lewin, Voor bijna alles bang geweest (Amsterdam: Singel, 1996), 318-319.

23. Interview with Jaap, May 17, 2018.

24. “Wat te doen met massamedia, bevechten of gebruiken?,” Dusnieuws, no. 11 (March 1999).

25. Dusnieuws cited in Donicie, “Eurodusnie”, 178.

26. “De Euro-taart-media-connection: Zelfinterview van een Dusnieuws-redacteur over de vervloekte kapitalistische, imperialistische massa-media”, Dusnieuws, no. 10 (January 1999).

27. Umberto Eco discussed such forms of activism as that of the 'semiological guerrilla', and stated that 'The battle for the survival of man as a responsible being in the Communications Era is not to be won where the communication originates, but where it arrives,' as well as defining this approach of the semiological guerrilla as 'the constant correction of perspectives, the checking of codes, the ever renewed interpretations of mass messages.' Umberto Eco, Travels in Hyperreality, (London: Picador, 1997), 135-144. The history, theory and various practices of communication guerrilla are discussed in: Autonome a.f.r.i.k.a. Gruppe et al., Handbuch der Kommunikationsguerrilla (Berlin/Hamburg: Assoziation A, 2012).

28. “Redactioneel,” Dusnieuws, no. 9 (1998).

29. Interview with Marco van Duijn, March 5, 2018. See also: Eric Krebbers and Harry Westerink "Journalist Wim Koevoet: 'Niveau Leidse politiek verbazingwekkend slecht,’” De Peueraar, no. 51 (November 1994).

30. Interview with Wim Koevoet, April 13, 2018.

31. Interview with Binnert Glastra, 11 April 2018. 
32. Rucht, "The Quadruple 'A'”.

33. Harderwijk is a small town, situated some 100 kilometres from Leiden.

34. Aad Rietveld, “Actievoerders richten ravage aan,” Leidsch Dagblad, April 14, 1998.

35. Rietveld, "Actievoerders".

36. Gerry van Bakel, “'De schade die McDonald's aanricht is veel groter',” Leidsch Dagblad, April 15, 1998.

37. Ad van Kaam, “Politie grijpt in bij actie tegen Pharming,” Leidsch Dagblad, April 15, 1998.

38. Herman Joustra, “Eurodusnie ontkent actieve rol in actie bij McDonald's,” Leidsch Dagblad, April 18, 1998.

39. Marcel Bas, “Actiegroep ‘Eurodusnie’ is dubieus zooitje ongeregeld,” Leidsch Dagblad, April 25, 1998.

40. Wim Wegman, “Koninklijk bezoek aan een benarde vest,” Leidsch Dagblad, December 30, 2000.

41. Ruud Sep, “Geen maatregelen tegen actiedreiging op Koninginnedag,” Leidsch Dagblad, June 14, 2000.

42. “Bea en de nationalistische eenheidsworst,” Dusnieuws, no. 20 (March 2000).

43. “Beatrix bezoekt Leiden: Exclusief interview met Comodo,” Dusnieuws, no. 20 (March 2000).

44. Ibid.

45. “Geen rellen op Koninginnedag,” Leidsch Dagblad, March 29, 2000.

46. "Beatrix bezoekt Leiden"; Wim Wegman and Annet van Aarsen, "Ommetje van de koningin is goed voor het plaveisel,” Leidsch Dagblad, April 7, 2000.

47. “Demonstratie Comodo verloopt probleemloos,” Leidsch Dagblad, May 1, 2000.

48. Wim Wegman, “Koninklijk bezoek aan een benarde vest," Leidsch Dagblad, December 30, 2000.

49. Wim Koevoet, "Lemstra staat achter omstreden politieoptreden," Leidsch Dagblad, July 2, 2002; Wim Koevoet, "Politie liegt in rapport over ontruiming Burcht," Leidsch Dagblad, July 4, 2002; Wim Koevoet, “Politie onder vuur in Burchtkwestie," Leidsch Dagblad, July 5, 2002; Annet van Aarsen, “In tien minuten staat iedereen buiten," Leidsch Dagblad, June 3 2002; Annet van Aarsen, “PvdA: Onderzoek actie politie bij Eurodusnie," Leidsch Dagblad, June 52002.

50. Koevoet, "Politie liegt".

51. “Internationale gasten Eurodusnie,” Leidsch Dagblad, August 31, 2002.

52. “Eurodusnie begrijpt angst voor zijn tentenkamp niet," Leidsch Dagblad, August 10, 2002.

53. Wim Koevoet, “Het is hier een productief zooitje,” Leidsch Dagblad, September 2, 2002.

54. The act of pie-throwing was politicised in the early 1970s by US American radicals Tom Forcade, editor of the underground newspaper High Times, and yippie activist Aron Kay. Eurodusnie's pie-throwing campaign was inspired by the actions of Noël Godin - who, in 1998, pied software industrialist Bill Gates - and the San Francisco anarchist group Biotic Baking Brigade. Ana M. Cox, “The Medium is the Meringue: 
Pie-throwing Protesters Who Take Their Slapstick Seriously,” Mother Jones, March/April 1999, https://www. motherjones.com/politics/1999/03/medium-meringue; Ben Paynter, "How Pie Became a Powerful Punchline in Political Provocation," Fast Company, November 20, 2017 https://www.fastcompany. com/40467645/how-pie-became-a-powerful-punchline-in-political-provocation; Gregory Lewis, "Piepitch Recipe: Activism with Humor," SF Gate, November 9, 1998, https://www.sfgate.com/news/article/ Pie-pitch-recipe-Activism-with-humor-3060366.php.

55. “Friedman met taart bekogeld," Dusnieuws, no. 8 (1998).

56. Ruud Sep, “Taart voor Van der Sluijs,” Leidsch Dagblad, April 6, 1998.

57. Interview with Marco van Duijn, March 5, 2018.

58. Interview with Jaap, May 17, 2018.

59. Sep, “Taart voor Van der Sluijs”.

60. The term 'Werpgroep' is a portmanteau of 'werkgroep' (i.e., task force) and 'werp' (i.e., 'throw'). The acronym TAART (pie) represents ‘Tegen Autoritaire en Anti-Revolutionaire Types’ - i.e., 'Against Authoritarian and Anti-Revolutionary Individuals'.

61. “Taart treft Bolkestein,” Leidsch Dagblad, December 3, 1998.

62. Ton van Brussel, “Taart in het gezicht van Bolkestein is wel nieuws," Leidsch Dagblad, December 9, 1998.

63. Van Brussel, “Taart in het gezicht”.

64. Rutger van der Hoeven, Sander Pleij, and Peter Vermaas, "Er moet een taart komen," Groene Amsterdammer, January 13, 1999, https://www.groene.nl/artikel/er-moet-een-taart-komen.

65. “Redactioneel,” Dusnieuws, no. 10 (January 1999).

66. “De Euro-taart-media-connection: Zelfinterview,” Dusnieuws, no. 10 (January 1999).

67. “Wat te doen met massamedia,” Dusnieuws, no. 11 (March 1999).

68. By the end of the 1990s, a group had split from Eurodusnie, with the members of this second group leaving Leiden. Two of them had been active in TAART before, and in 2002 they participated in the 'pieing' of Fortuyn. Neither TAART nor Eurodusnie, however, were involved in this action. Interview with Jaap, May 17, 2018.

69. Jos van Duinen, “Schrik zit er nog steeds in bij Eurodusnie na vernielingen,” Leidsch Dagblad, May 13, 2002.

70. Bill Meyer, “Taartgooiers,” Leidsch Dagblad, April 16, 2005.

71. W. Simons, “Vreugde bij Eurodusnie over subsidierel," Leidsch Dagblad, April 16, 2005.

72. In this respect, their media politics resemble those of the Dutch outlaw motorcycle gangs of recent years, trying their best to look cuddly and dangerous at the same time. See: Koetsenruijter and Burger, "Mannen met een hobby". 
73. Ibid.

74. An attack against mainstream news media by anarchists and autonomists took place in 1982, when activists stormed the Hamburg offices of Die Tageszeitung because of disagreements regarding the latter's reporting on a court case against two antinuclear activists; and in 1985, another attack took place in response to the same newspaper's printing of a critical interview with Bernhard Lochte, the local director of the Bundesnachrichtendienst (Federal Intelligence Service), who claimed that members of the Red Army Faction were housed at the squatted Hafenstrasse complex. For both incidents, see: Große Freiheit, no. 52 (June 1982); “Zunge ab,” Der Spiegel, no. 44 (October 28, 1985); Mathias Bröckers, Detlef Berentzen and Bernhard Brugger (eds.), Die Taz. Das Buch. Aktuelle Ewigkeitswerte aus Zehn Jahren 'Tageszeitung (Frankfurt am Main: Zweitausendeins, 1989), 649-650.

75. Vliegenthart and Walgrave, “The Interdependency of Mass Media and Social Movements”, 389.

76. Rucht, “The Quadruple 'A'”, 45-46.

77. Manning, News and News Sources, 17.

78. Deen Freelon, Alice Marwick, and Daniel Kreiss, “False Equivalencies: Online Activism From Left to Right,” Science 369, no. 6508 (2020), 1197-1201.

79. Yochai Benkler, Robert Faris, and Hal Roberts, Network Propaganda: Manipulation, Disinformation, and Radicalization in American Politics (Oxford: Oxford University Press, 2018).

80. When the Leiden chapter of the newly founded Socialist Party joined the council elections in 1974, its lead candidate stated in an interview: 'The national press ignores us, but in Leiden the situation is better.' Jan Hoekema, “Wij blijven een actiepartij, en worden geen praatpartij,” Nieuwe Leidsche Courant, May 7, 1974.

\section{Biographies}

Bart van der Steen is Subject Librarian at Leiden University Libraries. His research focuses on urban social and youth movements since the 1960s. Together with Peter Burger, he headed the research project 'Kraken in Leiden, 1970-2010', which digitally mapped all squatter actions in the city. His publications include Researching Subcultures, Myth and Memory (ed. with Th.P.F. Verburgh, Palgrave 2020) and A European Youth Revolt: European Perspectives on Youth Protest and Social Movements in the 1980s (ed. with K. Andresen, Palgrave, 2016). 
Peter Burger is an Assistant Professor at the Department of Journalism and New Media at Leiden University. He applies rhetorical perspectives to journalism, narrative folklore, and social media discourse.

Marcha van Wijk graduated from Leiden University in 2019 with a BA in Cultural Anthropology and Development Sociology. Her main research fields are squatting and the right to the city. She was involved in the research project 'Kraken in Leiden, 1970-2010', where she mainly focused on the anarchist group Eurodusnie.

TMG Journal for Media History

Volume 24 No (1/2)/2021

DOI

https://dx.doi.org/10.18146/tmg.800

PUBLISHER

Netherlands Institute for Sound and Vision

\section{COPYRIGHT}

Each article is copyrighted (c) by its author(s) and is published under license from the author(s). When a paper is accepted for publication, authors will be requested to agree with the Creative Commons Attribution 4.0 International License. 